\title{
The January 6 Insurrection and America's Standing Abroad: Natural Experimental Evidence from Five Unexpectedly Interrupted Public Opinion Surveys
}

\author{
Sam van Noort*
}

First version: December 8, 2021

This version: January 13, 2022

\begin{abstract}
American geopolitical power partly relies on foreign public support for its leadership. Pundits worry that this support is evaporating now that the United States - which claims to be the world's beacon of democracy - has itself experienced democratic backsliding. I provide the first natural experimental test of this hypothesis by exploiting that the January 6 insurrection of the US Capitol unexpectedly occurred while Gallup was conducting nationally-representative surveys in India, Indonesia, Malaysia, Romania, and Vietnam. Because Gallup uses random digit dialing I can identify the effect by comparing US leadership approval among respondents that were interviewed just before, and just after, January 6, 2021. I find that the insurrection had no effect on US approval. If even a violent attempt to overturn a free and fair election does not affect US approval abroad it is unlikely that any other domestic anti-democratic event will.
\end{abstract}

Keywords: Soft Power, Democratic Backsliding, United States

Word total: 4,008 (excl. abstract and online appendix)

${ }^{*}$ Postdoctoral Research Associate at Princeton University. E-mail address: samvannoort@princeton.edu Website: sites.google.com/view/samvannoort. 
"[But] in inciting violence against the very government he leads and turning the country into an object of pity and scorn all over the world, Trump has depleted the resources that fuel America's soft power." (Axe, 2021)

"The allure of democracy was the nation's best asset abroad, but the president squandered it by inciting political violence." Applebaum, 2021)

\section{Introduction}

The United States (US) has long held a special place in the world in terms of global public support for its leadership. This global public support for US leadership has been important. It has increased support for US military missions (Goldsmith and Horiuchi, 2012), it has helped to delegitimize terrorist attacks against American citizens (Chiozza, 2015), it has enabled the US to establish military bases in more than 80 countries in all parts of the world (Bitar, 2016), and it has allowed the US to have an outsized influence in the United Nations (Datta, 2009). Support for US leadership has not only been important for the achievement of US foreign policy goals. Indeed, Levitsky and Way (2010) find that in the post-Cold War period democratic transitions have been more likely to occur in countries where the US has significant legitimacy and leverage.

Much work in International Relations suggests that the US' unusual level of legitimacy as a global superpower significantly depends on its image as a beacon of democracy (e.g., Nye (2004). 1 By extension many scholars now worry that the January 6 insurrection of the US Capitol - a clear and highly salient case of democratic backsliding within the US - has significantly harmed America's standing abroad. Nye (2021), the leading scholar on "soft power", argues, for example, that:

"President Donald Trump's term in office was not kind to American soft power. [...] But even more damaging to US soft power was Trump's effort to disrupt the orderly transition of political power after he lost the 2020 election. And on

\footnotetext{
${ }^{1}$ See Appendix A for a short overview of this literature.
} 
January 6, 2021, as Republican Senator Ben Sasse described the invasion of the US Capitol, "the world's greatest symbol of self-government was ransacked while the leader of the free world cowered behind his keyboard tweeting against his Vice President for fulfilling the duties of his oath to the Constitution." America's allies and other countries were shocked, and America's attractiveness was diminished."

But did the January 6 insurrection indeed cause support for US leadership to decline? Or is foreign support for US leadership perhaps not so strongly reliant on the US actually living up to its mantra of a beacon of democracy?

I use a novel multi-country natural experiment to provide the, to the best of my knowledge, first econometrically well-identified answer to this crucial question. To do so I exploit that the January 6 insurrection of the US Capitol unexpectedly occurred while the World Gallup Poll was conducting nationally-representative public opinion surveys in India, Indonesia, Malaysia, Romania, and Vietnam. Because the insurrection was unexpected to foreign publics, did no coincide with other events that could plausibly affect US leadership approval, and because Gallup samples respondents using random digit dialing I can identify the effect of the insurrection by comparing US leadership approval among respondents that happened to be interviewed just before, and just after, January 6, 2021.

Surprisingly, the results suggest that the January 6 insurrection did not affect support for US leadership. This is true regardless of whether one compares respondents that were interviewed on January 5 and January 7 , or when one compares respondents that were interviewed in the weeks before and after the event. The result also remains unchanged when using different sets of controls, estimators, probability weights, and coding rules. Importantly, the large sample size $(\mathrm{N}=4,317)$ allows me to exclude with great certainty that this result is driven by a lack of statistical power.

In terms of causal mechanisms I am able to exclude three plausible channels that could in theory explain why the January 6 insurrection did not depress support for US leadership. First, I analyze google trends and newspaper data and find that it is unlikely that the results are driven by a lack of information regarding the January 6 insurrection in India, 
Indonesia, Malaysia, Romania, and Vietnam. Second, I analyze support for US leadership before January 6 and find that the results are unlikely to be driven by support for US leadership already being so low before January 6, 2021 that there was little room for further negative adjustment. Last, I analyze survey data from a wide range of sources and find that the results are unlikely to be driven by the US before January 6, 2021 not being seen as a beacon of democracy to begin with.

I interpret these results as suggesting that the null effect of the January 6 insurrection on US foreign leadership approval is simply driven by foreign publics conditioning their support for US leadership solely on other factors outside domestic events related to American democracy. This may be explained by the fact that anti-democratic events within the US arguably have little direct influence on the lives of foreign publics. If this is true one would expect that events in American politics that are more likely to directly affect foreign publicssuch as leadership changes - do affect US leadership approval. I find strong evidence that this is indeed the case. More specifically, I find that approval of US leadership increased with approximately $21.5 \%$ (or, approximately 0.43 standard deviations) after the inauguration of Joe Biden, which occurred on January 20, 2021 when World Gallup Polls were still ongoing in India, Malaysia, and Romania. This suggest that rather than the state of American democracy foreign public opinion appears mostly responsive to who the president of the US is and/or the content of US foreign policy (both of which changed on January 20, 2021).

The paper make several contributions. First, the paper is the first to naturally experimentally test the hypothesis that the state of American democracy causally affects support for US leadership on the international stage. Second, the paper is one of the first papers to rigorously examine the effects, rather than the causes, of democratic backsliding within the US 2 Third, the paper is one of the very few papers that rigorously test implications of soft

${ }^{2}$ Other research has focused on the effects of the January 6 insurrection within the US itself. It is interesting to note in this regard that the insurrection does appear to have had a major effect on US domestic public opinion (Van Noort, 2021). 
power theories in International Relations, something that has proven notoriously difficult to do (Goldsmith and Horiuchi, 2012). Last, the paper adds additional causal evidence in support of the work of Agadjanian and Horiuchi (2020), Bateson and Weintraub (Forthcoming), Carreras, Visconti and Acácio (Forthcoming), and Goldsmith and Horiuchi (2012), which suggests that the content of foreign policy and the identity of the president of the US strongly affects foreign approval of US leadership.

\section{The January 6 insurrection}

On November 3, 2020 Joe Biden (Democrat) won the US presidential election of sitting US president Donald Trump (Republican) with a little more than 7 million popular votes (and 74 Electoral College votes) difference. Despite this enormous difference in the number of votes, and the absence of any evidence of widespread voting fraud, Donald Trump claimed that the election was fraudulent and that he was the true winner of the election.

After several months of constant misinformation, and a wide range of highly publicized court cases (which were all dismissed for a lack of evidence), Donald Trump held a speech at the "Stop the Steal" rally on January 6, 2021. In the speech Trump said, among other things, that the election was stolen, that he and his supporter will never concede, that they will fight like hell, and that they are going to walk down to the US Capitol building because "you'll never take your country back with weakness" $3^{3}$

Directly after this speech a large mob of Trump supporters stormed the US Capitol building in an effort to stop the certification of Joe Biden as the upcoming president of the US. The insurrection lead to the death of 5 people, the injury of at least 138 police officers, physical property damages in excess of 30 million dollars, and the chaotic evacuation of all members of Congress.

I regard this event as a clear case of democratic backsliding that should be noticed and

\footnotetext{
${ }^{3}$ See appendix B for direct quotes from the speech.
} 
sanctioned as such if foreign publics are indeed conditioning their support for US leadership on domestic events related to American democracy.

\section{Data}

To test the effect of the January 6 insurrection on foreign public support for US leadership I make use of data from the World Gallup Poll. I make use of World Gallup Poll data because this is the only public opinion survey that regularly conducts surveys in virtually all countries in the world (making overlap with the insurrection event likely) while using random digit dialing for the recruitment of respondents (ensuring that assignment to treatment is random). In five countries - India, Indonesia, Malaysia, Romania, and Vietnam-World Gallup Polls were ongoing when the insurrection of the US Capitol occurred on January 6, 2021.4 Appendix C lists the fieldwork dates in each country.

As the dependent variable I use a dummy that takes the value 1 if a respondent approves of the job performance of the leadership of the US, and 0 if a respondent disapproves. This variable is regularly used in the existing literature to measure America's standing in the world (e.g., Goldsmith, Horiuchi and Wood (2014)). I drop respondents that answer that they don't know whether they approve or disapprove of US leadership. Results remain the same when including "don't know" responses in the 0 category.

As the treatment variable I use a dummy that takes the value 1 if a respondent was interviewed after January 6, 2021, and 0 if a respondent was interviewed before this date. I drop respondents that were interviewed on January 6 itself, as I cannot be certain whether

${ }^{4}$ The January 6 insurrection also overlapped with the fieldwork period in Pakistan. I exclude Pakistan because only 48 respondents were interviewed in Pakistan prior to January 6, 2021, and these respondents were interviewed on January 2 and 3 (no respondents were interviewed on January 4 and 5). Including Pakistan makes no substantive difference to the results. 
these respondents are treated or untreated (the World Gallup Poll does not provide data on the exact time of interview). Including these respondents in either the control or treatment group makes no substantive difference to the results.

\section{Identification strategy}

To identify the causal effect of the insurrection I employ a so-called "unexpected event during survey" design. Causal identification in these designs relies on two assumptions. First, temporal ignorability, meaning that whether any particular individual is interviewed before or after January 6 should be orthogonal to any other individual-level characteristic that also affects support for US leadership. Second, excludability, meaning that the timing of interview should affect support for US leadership only through the insurrection event, not through any other channel (Muñoz, Falcó-Gimeno and Hernández, 2020).

These identifying assumptions are likely to hold in this case. First, the World Gallup Poll samples respondents using random digit dialing. This ensures that any individual, regardless of his/her background characteristics, and regardless of where he/she lives, is equally likely to be interviewed on any particular day within the period that a World Gallup Poll is conducted. In line with this I find that the treatment and control groups are balanced on a number of pre-treatment variables that may also affect support for US leadership (see figure 1) $!^{5}$

Second, analysis of news media suggests that there were no other events on January 6 , 2021 that could plausibly have affected support for US leadership in foreign countries (see Appendix E).

Last, the insurrection of the US Capitol was plausibly unexpected to foreign publics. This makes it very unlikely that respondents that were interviewed prior to January 6, 2021 had already changed their approval of US leadership in expectation of the insurrection.

\footnotetext{
${ }^{5}$ See Appendix D for the measurement of these covariates.
} 
Figure 1: Balance on observables.

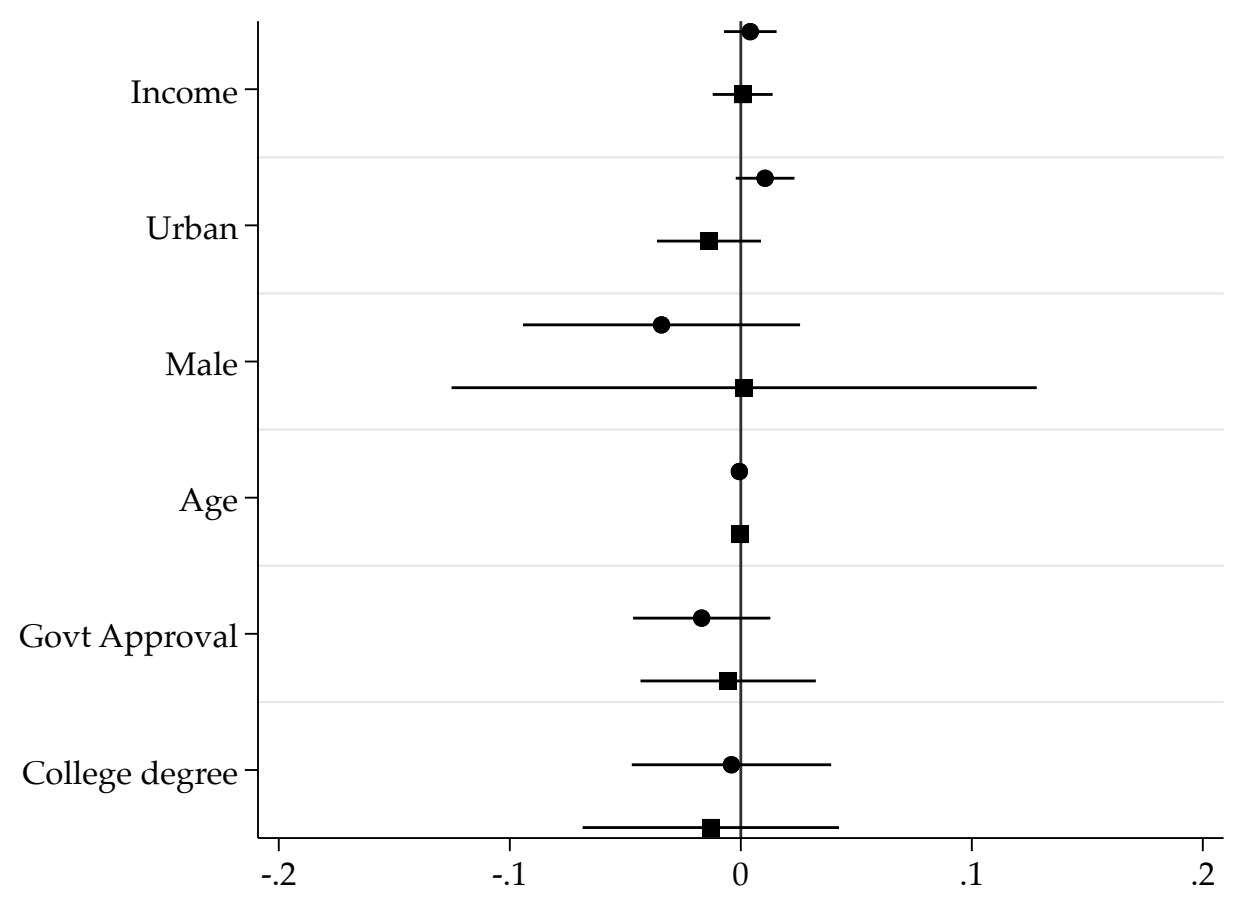

Note: OLS regressions. Dependent variable is treatment status. Point estimates and $95 \%$ confidence intervals are reported. Each line represents a separate regression. Confidence intervals are robust to heteroscedasticity and corrected for autocorrelation on the country-level. Countries included are: India, Indonesia, Malaysia, Romania, and Vietnam. Country fixed effects are included but omitted to save space. Dots are estimates in the full sample. Squares are estimates in the 1-day sample (i.e., only respondents that are interviewed on January 5 or January 7, 2021 are included). 


\section{Results}

In table 1 I use OLS to regress my US leadership approval dummy on a dummy capturing whether a respondent was interviewed before (category 0) or after (category 1) January 6, 2021. All regressions also include country fixed effects. Omitting these fixed effects makes no substantive difference to the results.

Column (1) shows that respondents that were interviewed before January 6, 2021 were on average $1 \%$ less supportive of US leadership, as compared to respondents that were interviewed after January 6. This effect is miniscule as compared to the pre-treatment mean of US leadership approval, and is highly statistically insignificant (P-value: 0.711). Columns (2), (3), and (4) show that similar estimates are obtained when restricting the sample to only include respondents that were interviewed in the 7, 2, and 1 days before and after January 6, 2021.

This null result remains unchanged: (1) when using the probability weights provided by Gallup to increase the population-wide representativeness of the data (Panel B of table 1); (2) when adding the covariates from figure 1 (Appendix F); (3) when using logit or probit estimation instead of OLS (Appendix G); and (4) when analyzing the effect for each country individually (Appendix H) $!^{6}$

Taken together the results suggests that the January 6 insurrection had on average no effect on US leadership approval in India, Indonesia, Malaysia, Romania, and Vietnam. Crucially, this null effect is not due to a lack of statistical power. For example, the baseline estimate in panel A column (1) suggests that two standard error bands exclude effects greater than $-6.2 \%$. Even this effect is only $11.8 \%$ of the pre-treatment mean, and within all countries insufficient to change the relative order of approval between the US, China, and Russia.

${ }^{6}$ The exception is Romania. Here I do find a significant negative effect of the insurrection. This effect is, however, entirely offset by the positive effect of Donald Trump's replacement by Joe Biden on January 20, 2021 (see next section). 
Table 1: Effect of January 6 insurrection of the US Capitol.

$(1) \quad(2) \quad(3) \quad$ (4)

Panel A: Sample average treatment effect (SATE)

$\begin{array}{lcccc}\text { 6 January 2021 } & -0.010 & -0.005 & -0.009 & -0.046 \\ & (0.026) & (0.032) & (0.048) & (0.053) \\ \text { Mean of DV } & & & & \\ \text { Days pre/post } & 0.527 & 0.570 & 0.558 & 0.563 \\ \text { Country FE } & \text { All } & 7 & 2 & 1 \\ \mathrm{~N} & \text { Yes } & \text { Yes } & \text { Yes } & \text { Yes } \\ & 4317 & 2476 & 923 & 472\end{array}$

Panel B: Population average treatment effect (PATE)

$\begin{array}{lcccc}\text { 6 January 2021 } & -0.035 & -0.035 & -0.034 & -0.084 \\ & (0.021) & (0.026) & (0.039) & (0.054) \\ \text { Mean of DV } & & & & \\ \text { Days pre/post } & 0.527 & 0.578 & 0.570 & 0.581 \\ \text { Country FE } & \text { All } & 7 & 2 & 1 \\ \mathrm{~N} & \text { Yes } & \text { Yes } & \text { Yes } & \text { Yes } \\ & 4317 & 2476 & 923 & 472\end{array}$

Notes: Each column within panel A and B is a separate OLS regression. The dependent variable is a dummy that takes the value 1 if a respondent approves of the job performance of the leadership of the US, and 0 if a respondent disapproves. The independent variable is a dummy that takes the value 1 if a respondent is surveyed after January 6, 2021, and 0 if a respondent is surveyed before this day. Countries included are: India, Indonesia, Malaysia, Romania, and Vietnam. All regressions include country fixed effects. Robust standard errors clustered on the country-level are reported in parentheses. The mean of the dependent variable is measured among all respondents that were interviewed before January 6, 2021. Panel B uses the household probability weights provided by Gallup.

$* * * \mathrm{p}<0.001, * * \mathrm{p}<0.01, * \mathrm{p}<0.05$. 


\section{Causal mechanism}

A natural question to ask is why the peoples of India, Indonesia, Malaysia, Romania, and Vietnam did not lower their support for US leadership as a result of the January 6 insurrection, even through the "beacon of democracy" hypothesis suggests that they would. I here examine four possible mechanisms.

Lack of information: Appendix I shows that the null effect is unlikely to be due to people in India, Indonesia, Malaysia, Romania, and Vietnam being simply insufficiently aware of the January 6 insurrection of the US Capitol. 7 The insurrection of the US Capitol was on the front page of each country' most-read newspaper on January 7, 2021, google trends data suggests that searches with the terms "US", "Trump", and "Capitol" were among the most common searches in all five countries right after January 6, 2021, and qualitative accounts of journalists stationed in foreign countries during the insurrection suggest that the events were followed closely by foreign publics.

Floor effects: The null effect is also unlikely to be driven by support for the US already being so low before January 6, 2021 that there was little scope for further decline. Approval of US leadership in the week before January 6 was $58.7 \%, 40.9 \%, 35.8 \%, 54.2 \%$, and $81.5 \%$ in India, Indonesia, Malaysia, Romania, and Vietnam, respectively. Support for China in these same countries was meanwhile only $14.8 \%, 35.9 \%, 50.0 \%, 39.0 \%$, and $16.2 \%$, respectively.

The US not seen as a beacon of democracy to begin with: Appendix J suggests that the null effect is also unlikely to be explained by the US not being seen as a beacon of democracy before January 6, 2021 to begin with. Data from the Eurasia Group Foundation

${ }^{7}$ Note that the possibility of a lack of information does not invalidate my identification strategy. This is because knowledge of the democratic backsliding event is itself part of the process of theoretical interest. If even something as extreme as an attempt to violently overturn the results of a free and fair election is insufficient for foreign peoples to be informed about the state of American democracy, it is save to assume that no democratic backsliding event will substantively move foreign support for US leadership. 
suggests, for example, that over $80 \%$ of Indians held positive opinions of "American-style" democracy as late as 2020. Data for the other four countries is more sporadic, but does generally point in the same direction.

\section{Foreign publics condition their support for US leadership on other factors:}

The above appears to leave room for only one last mechanism-people in India, Indonesia, Malaysia, Romania, and Vietnam simply condition their support for US leadership on other variables than the functioning of American democracy. This may be explained by the fact that democratic backsliding events within the US are arguably highly unlikely to directly affect the lives of people living in India, Indonesia, Malaysia, Romania, and Vietnam. If so, one would expect to find strong effects of events that are more likely to affect the lives of foreign publics - such as changes in US leadership and changes in US foreign policy. In line with this conjecture I find that the replacement of Donald Trump by Joe Biden on January 20, 2021, which occurred while World Gallup Polls were still ongoing in India, Malaysia, and Romania, and which represented a sea-shift in US leadership and foreign policy, did strongly affect support for US leadership (see table 2) 8 This result is in line with the work of Agadjanian and Horiuchi (2020), Bateson and Weintraub (Forthcoming), Carreras, Visconti and Acácio (Forthcoming), and Goldsmith and Horiuchi (2012) who have shown that support for US leadership is strongly affected by the content of foreign policy and the identify of the US president.9

${ }^{8}$ Note that support went up in all countries, and this result is highly robust to controls and probit/logit estimation (see Appendices F, G, and H).

${ }^{9}$ In this case the identity of the president and the content of foreign policy arguably both changed with the replacement of Donald Trump by Joe Biden, making it difficult to cleanly separate these two distinct mechanisms. Agadjanian and Horiuchi (2020) attempt to decompose the effect of the content of foreign policy and the identity of the US president using a survey experiment. They find that both matter but that the content of foreign policy matters more. 
Table 2: Effect of January 20 inauguration of president Biden.

\section{$(1)$} $(2)$

$(3)$

$(4)$

Panel A: Sample average treatment effect (SATE)

$\begin{array}{lcccc}\text { 20 January 2021 } & 0.215^{* * *} & 0.212^{* *} & 0.237^{* *} & 0.316^{*} \\ & (0.022) & (0.034) & (0.016) & (0.043) \\ \text { Mean of DV } & & & & \\ \text { Days pre/post } & 0.537 & 0.528 & 0.551 & 0.526 \\ \text { Country FE } & \text { All } & 7 & 2 & 1 \\ \mathrm{~N} & \text { Yes } & \text { Yes } & \text { Yes } & \text { Yes } \\ & 2778 & 1393 & 466 & 245\end{array}$

Panel B: Population average treatment effect (PATE)

$\begin{array}{lcccc}\text { 20 January 2021 } & 0.182^{* * *} & 0.166^{* * *} & 0.190^{* * *} & 0.235^{* * *} \\ & (0.036) & (0.039) & (0.055) & (0.069) \\ \text { Mean of DV } & & & 0.552 & 0.565 \\ \text { Days pre/post } & 0.522 & 0.527 & 2 & 1 \\ \text { Country FE } & \text { All } & 7 & \text { Yes } & \text { Yes } \\ \text { N } & \text { Yes } & \text { Yes } & 466 & 245\end{array}$

Notes: Each column within panel A and B is a separate OLS regression. The dependent variable is a dummy that takes the value 1 if a respondent approves of the job performance of the leadership of the US, and 0 if a respondent disapproves. The independent variable is a dummy that takes the value 1 if a respondent is surveyed after January 6,2021, and 0 if a respondent is surveyed before this day. Countries included are: India, Malaysia, and Romania. All regressions include country fixed effects. Robust standard errors clustered on the country-level are reported in parentheses. The mean of the dependent variable is measured among all respondents that were interviewed before January 20, 2021. Panel B uses the household probability weights provided by Gallup.

$* * * \mathrm{p}<0.001, * * \mathrm{p}<0.01, * \mathrm{p}<0.05$. 


\section{Discussion}

The novel multi-country natural experiment exploited in this paper allows me to state with great certainly that the January 6 insurrection did not have a significant effect on US leadership approval in India, Indonesia, Malaysia, Romania, and Vietnam. While these countries in themselves house approximately 1.8 billion people - or, $23.1 \%$ of the world's populationan important question for future research remains whether these results also generalize to

other countries. It is theoretically possible that publics in other countries outside of India, Indonesia, Malaysia, Romania, and Vietnam value domestic American democracy more in their judgment of US leadership. But even if this is indeed the case existing theory with regard to the "beacon of democracy" hypothesis should be framed in more conditional terms that it currently is.

Another important question for future research is how the results of this paper generalize to other "type" of democratic backsliding treatments. On the one hand, one could argue that a violent attempt to overturn the results of a free and fair election is close to a most-likely case for the hypothesis that democratic backsliding within the US causes foreign support for US leadership to decline. On the other hand, one could imagine that the accumulation of many different democratic backsliding events within the US could eventually erode global support for US leadership. 


\section{References}

Agadjanian, Alexander and Yusaku Horiuchi. 2020. "Has Trump Damaged the US Image Abroad? Decomposing the Effects of Policy Messages on Foreign Public Opinion." Political Behavior 42(2):581-602.

Applebaum, Anne. 2021. "What Trump and His Mob Taught the World About America." The Atlantic, January 7, 2021.

Axe, David. 2021. "Venezuela Is Worried About America-That's A Big Problem For U.S. Influence in The World." Forbes, January 7, 2021.

Bateson, Regina and Michael Weintraub. Forthcoming. "The 2016 Election and America's Standing Abroad: Quasi-Experimental Evidence of a Trump Effect." Journal of Politics .

Bitar, Sebastian E. 2016. US Military Bases, Quasi-Bases, and Domestic Politics in Latin America. Springer.

Carreras, Miguel, Giancarlo Visconti and Igor Acácio. Forthcoming. "The Trump Election and Attitudes Toward the United States in Latin America." Public Opinion Quarterly .

Chiozza, Giacomo. 2015. "Does US Soft Power Have Consequences for US Security? Evidence from Popular Support for Suicide Bombing." Korean Journal of International Studies 13(1):207-237.

Datta, Monti Narayan. 2009. "The Decline of America's Soft Power in the United Nations." International Studies Perspectives 10(3):265-284.

Goldsmith, Benjamin E. and Yusaku Horiuchi. 2012. "In Search of Soft Power: Does Foreign Public Opinion Matter for US Foreign Policy?" World Politics 64(3):555-585.

Goldsmith, Benjamin E., Yusaku Horiuchi and Terence Wood. 2014. "Doing Well by Doing Good: The Impact of Foreign Aid on Foreign Public Opinion." Quarterly Journal of Political Science 9(1):87-114.

Levitsky, Steven and Lucan A. Way. 2010. Competitive Authoritarianism: Hybrid Regimes after the Cold War. Cambridge University Press.

Muñoz, Jordi, Albert Falcó-Gimeno and Enrique Hernández. 2020. "Unexpected Event 
during Survey Design: Promise and Pitfalls for Causal Inference." Political Analysis 28(2):186-206.

Nye, Joseph. 2021. "American Democracy and Soft Power." Project Syndicate, November 2, 2021.

Nye, Joseph S. 2004. Soft Power: The Means to Success in World Politics. Public Affairs. Van Noort, Sam. 2021. "American Voters Do Punish Overt Undemocratic Behavior at the Polls: Natural Experimental Evidence from the 2021 Insurrection of the U.S. Capitol." APSA Preprints. 